\title{
STUDENTS' PERCEPTION TOWARD TEACHING ENGLISH VOCABULARY THROUGH TOTAL PHYSICAL RESPONSE (TPR) METHOD
}

\author{
Achmad Taufiq Ibrohim ${ }^{1}$, Astri Septianti ${ }^{2}$ \\ Irma Savitri Sadikin ${ }^{3}$ \\ ${ }^{1}$ IKIP SILIW ANGI \\ ${ }^{2}$ IKIP SILIWANGI \\ ${ }^{3}$ IKIP SILIWANGI \\ ${ }^{1}$ achmadtaufiq02@gmail.com, ${ }^{2}$ astriseptianty.as@gmail.com, \\ savitrisadikin@ikipsiliwangi.ac.id
}

\begin{abstract}
The objective of the research is to investigate the students' perception on teaching english vocabulary through Total Physical Response (TPR) technique and to identify the benefits that the students obtained from that technique. This research used a qualitative descriptive research method. The respondents of the research were eight grade students of SMPN 2 Plered Purwakarta. The data were obtained from questionaire and interview. The results of the study that the teaching english vocabulary through Total Physical Response (TPR) technique could help students' vocabulary in learning english. Based on interview and questionnaire, they showed some improvement on process of get new vocabulary from learning with that technique. Moreover, the data from questionaire and interview showed that there were some benefits of TPR method: 1. Developt of students' speaking ability and increasing vocabulary, 2. Increasing the students participation in the class, 3. Having a fun learning atmosphere.
\end{abstract}

Keywords: Vocabulary, Total Physical Response(TPR), Students' Perception.

\section{INTRODUCTION}

Speaking is one of language skills that have to be mastered by the students. According to Depdiknas (2003:6), English learning process includes listening, reading, speaking, and writing as the form of spoken and written cycle. Brown (2004) states that emphasizes that speaking skillis a skill in producing an oral language. Surely, in daily interaction, we use speaking as a mean of communication although we cannot ignore the significance of writing, as another of communication, which is still popular to the people. This condition is more supported by the existence of technology: such as telephone.

According to explanation above, we can conclude that speaking is one of important skill in learning english. It can be also make their self confidence to speak english and communicate to each other. There are many kinds of speaking skill, one kind of the speaking skill is vocabulary.

Lack of vocabulary can be a crucial factor underlying the school failure of disadventaged students (Becker; Bergland, 2014). Based on Alqathani (2015) vocabulary knowledge (mastery) is often viewed as a critical tool for second language learners because a limited vocabulary in a second language impedes successful communication. Alqathani (2015) 
also said that the meaning of vocabulary mastery is the reportory of vocabulary owned by someone that can be used appropriately by the reading context.

Vocabulary is important in learning english too. Many students have problem with their vocabulary, that is why many students have not to learning english because they do not know vocabulary in English besides they are shy to speak english.

To solve this problem, the writters use one of technique types in learning English. That technique is Total Physical Response (TPR) to help students' on their vocabulary in learning English.

\section{1) Teaching Vocabulary}

Vocabulary in the foundantion produce languages, which plays a fundamental role in communication. Thus, vocabulary is very important role in communication with pople in the wolrd (Hatch and Brown, 1995:1). Vocabulary plays significant role for language skills (listening, speaking, reading, writing). In addition, vocabulary is central to the learning of a foreign language at primary level (Cameron, 2001:72). Its means that learning vocabulary is very important as the basic need to get a new language. However, many english learners have difficulties when learn vocabulary. Therefore, teacher should provide some techniques to make students to be able to learn vocabulary is for their English language.

Vocabulary teaching is one of the most important components at many language classes. The main problem in teaching and learning vocabulary is a technique in teaching vocabulary that less of varation. In the class that the writer observed, the teacher teaches vocabulary based on material of the day, then translate the meaning one by one. After that, teacher reads the vocabulary and the student repeats what the teacher said. Teacher gives about 5 until 10 minutes to memorize those vocabulary randomly.

Learning vocabulary is very needed for the students. Some student think it is difficult to memorize English vocabulary because they not interested and rarely to use that vocabulary in their daily life.

In fact, the teacher must be able to choose a good technique to improve the students' vocabulary. The students sometimes get boried when learning English, because they think English is hard to learn.

\section{2) Teaching Vocabulary Through Total Physical Response}

Teaching vocabulary through Totaly Physical Response is one of the ways in achieving vocabularies for the students. Sadikin (2016:406) stated that in teaching new word in a foreign language, a teacher should consider that young learners are still building up their first language vocabulary and are still in process of acquiring and organizing concepts. Through Totaly Physical Response, it will motivate the students to have high response in learning foreign language, to have discipline and discover new words, because it will force the students to look for new words and guess it, even they can perform in front of class to explore the meaning of words. The teacher would give the lists of vocabulary and the meaning first, and then asks students to memorize it.

Total Physical Response was firstly proposed by James T. Asher (1960). In Total Physical Response, a physical movement is used in responding what student hear from the teacher's talk. Pinter (2006: 50) has stated that "TPR links learning to phisical action and ensures that learners will hear a lot of natural English in meaningful context without having to response verbally. According to Richard and Rodgers (2001: 73) "TPR is a language teaching method built around the coordination of speech and action; it attempts to each language through physical (motor) activity. 
Based on the definiton above it can be conclude that TPR is a language teaching method which combine teacher's instruction (what students hear) and physical response (students' response)

\section{3) The Objective and Advantages Total Physical Response (TPR)}

Total physical Response (TPR) method has very important objective. The general objectives of total physical Total Physical Response are to teach oral proficiency at a beginning level (Richard \& Rodgers, 1986:91). It shows that students in the beginning lvel will be helped in oral proficiency using TPR. Not only in oral proficiency, but also students could increase their vocabulary mastery in English.

Nunan (1991: 224) stated that we should provide input to the learners by getting them to carry out command. This command should be couched in the imperative, Using TPR method in English usually involved command drill, so students would accept a lot of exposure language in listening that increase their vocabulary mastery.

Richard \& Rodgers (1986: 92) argued that the movement of the body seems to be a powerful mediator for the understanding, organizing and storage of macro-detail of linguistic input. Language can be internalized in chunks, but alternative strategies must be developed for line-tuning to macro-details. The body movement can be mediator for understanding the language. It will support the development of the students in getting so much inputs of language. It means that the movement of the body when studying can be a mediator for students to reach the knowledge.

The TPR method has many advantages. Widodo (2005) has collected the advantages of the TPR method. The first, it is a sucessful teaching method that can be used for both children and adults. The second, it is very memorable. It can assist pupils to remember phrases or words. The third, it is a lot of fun, learners enjoy it. It can actually lift pace and mood. The fourth, they can make the teaching more enjoyable for both teachers and pupils. The fifth, it is suitable for the children who are required to be active in the class. The sixth, there is no matter with how many pupils involved, as long as teachers are prepared to take the lead, the laerners will follow. The seventh, it also can be used in the mixed-ability classes. The physical actions and the picture enable all the learners to comprehend the target language effectively. The eight, it is effective for the young learners. And the last, the TPR method needs the coordination of both the right and left hemisphere of the human brain.

\section{4) Student's Perception}

Perception is a psychology process where the stimulus received by individuals and the data processed well, so that the stimulus grts a meaning (Suryana, 2004). Human is a creature who can receive information well and interpret it differently one from another. In the process of interpreting, perception occurs.

The more complex definiton is given by Pareek who states that perception is a procces of receiving, selecting, organizing, interpreting, evaluating, and giving reaction to stimuli of the senses or data (Alex, 2003: 446). In addition, Baron (1995: 90) states that perception is the process through selecting, organizing, and interpreting input from the sensory receptors. Perception describe people's through abut the information they get as the stimuli received and influenced by experiented background.

As stated in the concept of perception before, perception can be defined as the process of how the information is acquired through the sensory receptors (e.g eyes, ears, nose and skin) which is transformed into a perception of what we think, see, hear, smell, taste, or touch (Mussen, 1973). In addition Walgito (2001) also states that perception which is begun by the pocess of feeling of measuring something; this is also the process of accepting stimuli by individual through sense organs or it also called sensory process. Thus it can be summarized that students' perception is the way student acquires information of the world or something 
through the process of feeling and measuring its stimuli and processes it to become a perception of what he/ she think, smell, hear, see, taste, or touch.

Based on the explanation above we can conclude that perception is the process by which we interpret the world around us, forming a mentral representation of the environment.

\section{RESEARCH METHOD}

\section{1) Research Method}

The method used in this research was descriptive qualitative research method. In relation to this research, descriptive qualitative method was choosen because the research will present a description about the students' perception towards teaching vocabulary through TPR method and at the end build a conclusion based on the data gained. According to Alwasilah (2002) descriptive research describes characteristics or identifies a group, accident and phenemenon by which the technique commonly used to measure three things, they are: 1) the existence and distribution of various behaviour or characteristics that occur naturally; 2) frequency occurs in nature; 3) relationship and magnitude relationship that may exist between the characteristics, bahaviour, events, or phenomena of concern to the research. In addition, Creswell (1994) assumed the descriptive method of research is to gain information about the resent existing condition also to asses hypothesis or question concerning the current situation of the research.

\section{2) Research Instrument}

1. Qustionnaire

In this research questionnaire was used to gain the information about students' perception towards teaching vocabulary through TPR method in school. Alwasilah (2002: 152) stated that the aim of questionnaire is to identify subject's attitude, opinion, or perception.

\section{Interview}

Interview was used to gain the supporting data the researcher could not get through questionnaire. According to Walker (1985), the interview is method a group of techniques specific to the social and human sciencies. It conclude a wide range of techniques, from the structured questionnaire through to the understand conversation, but it all hinge on the assumption that people are, to some degree, reflective about their own action.

\section{3) Research Population and Sample}

The population of this research is follow :

1. Population

McMilan (2001: 169) stated that "A population is a group of element or cases, wheter individuals, object, or evens that confrom to specific criteria and to which we intended to generalize the result of the research".

The population of this research, the writer will take the students of eight grade SMPN 2 Plered academic year 2016-2017 and students' perception.

\section{Sample}

Based on McMilan (2001 : 169), the sample can be selected from a larger group or persons, identified as the population or it can simply refer to the group or subjects from whom data are collected (even thought the subjects are not selected for the population). 
The sample of this researchwas15students of the eight grade of SMPN 2 Plered in academic year 2016-2017.

\section{4) Research Data Collection}

1. Questionnaire

Questionnaire is a form used in a survey design that respondents in a research complete and return to the writer. The respondent chooses answers to question and supplies basic personal or demographic information. Arikunto says that a questionnire is a number of written questions which are used to gain information from the respondents about themselves or their knowledge, belief etc. (2002: 128).

Processing the data using statistics percentage by making tables in coloum.

In this stage, the frequently of students who answered closed questionnaire is calculated in percentage from using the formula:

$$
\mathbf{P}=\frac{F o}{\mathbf{N}} X 100 \%
$$

(Sudjana, 1984: 46)

$\mathrm{P}=$ Percentage $(\%)$

$F o=$ Total respondents who answer an item

$\mathrm{N}=$ Total respondents

\section{Interview}

According to Arikunto (2002: 132) pointed out than an interview is a dialogue between an interviewer and the respondents about a certain topic with the purpose to obtain more information. Interview was conduted after the students answering questionnaire. It was done to know students perception about teaching vocabulary throuh TPR method. Alwasiah (2008: 154) agues that interview was conducted in order to get in-depth from the subject research. In as indepth interview, people who the research can gain more information about the topic than students related to their response by using TPR method. The question in the interview has modifield based on Richard \& Rodgers (2001) TPR is teaching method that is based coordination language speaking and action, this is an attempt to each the language through prhysical activity.

\section{FINDING AND DISCUSSION}

\section{Finding}

This is table of quistionnaire and the result for students' perception on teaching english vocabulary through TPR method:

\begin{tabular}{|c|c|l|c|c|c|c|}
\hline Category & Number & \multicolumn{1}{|c|}{ Question } & $\begin{array}{c}\text { Strongly } \\
\text { Agree }\end{array}$ & Agree & Disagree & $\begin{array}{c}\text { Strongly } \\
\text { Disagree }\end{array}$ \\
\hline $\begin{array}{l}\text { 1. Students } \\
\text { Perception }\end{array}$ & 1. & $\begin{array}{l}\text { I feel easy learning } \\
\text { with this method }\end{array}$ & $86,66 \%$ & $13,33 \%$ & - & - \\
\hline
\end{tabular}




\begin{tabular}{|c|c|c|c|c|c|c|}
\hline \multirow[t]{4}{*}{$\begin{array}{l}\text { toward TPR } \\
\text { Method }\end{array}$} & 2. & $\begin{array}{l}\text { I understand lessons } \\
\text { more quickly using } \\
\text { this technique }\end{array}$ & $53,33 \%$ & $46,66 \%$ & - & - \\
\hline & 3. & $\begin{array}{l}\text { I feel enjoy and } \\
\text { active learning with } \\
\text { this method }\end{array}$ & $6,66 \%$ & $93,33 \%$ & - & - \\
\hline & 4. & $\begin{array}{l}\text { I get new } \\
\text { information thruogh } \\
\text { this method }\end{array}$ & $73,33 \%$ & $26,66 \%$ & - & - \\
\hline & 5. & $\begin{array}{l}\text { I love } \\
\text { learningvocabulary } \\
\text { by using this } \\
\text { method }\end{array}$ & $86,66 \%$ & $13,33 \%$ & - & - \\
\hline \multirow{5}{*}{$\begin{array}{l}\text { 2. The } \\
\text { Benefit of } \\
\text { TPR } \\
\text { Method }\end{array}$} & 6. & $\begin{array}{l}\text { I can get more } \\
\text { information using } \\
\text { this method }\end{array}$ & $20 \%$ & $80 \%$ & - & - \\
\hline & 7. & $\begin{array}{l}\text { I am able to learn } \\
\text { the material through } \\
\text { this method }\end{array}$ & $26,66 \%$ & $73,33 \%$ & - & - \\
\hline & 8. & $\begin{array}{l}\text { I feel happy to learn } \\
\text { through this method }\end{array}$ & $93,33 \%$ & $6,66 \%$ & - & - \\
\hline & 9. & $\begin{array}{l}\text { I can learn quickly } \\
\text { and easily }\end{array}$ & $66,66 \%$ & $33,33 \%$ & - & - \\
\hline & 10. & $\begin{array}{l}\text { I am motivated to } \\
\text { learn vocabulary } \\
\text { thorugh this method }\end{array}$ & $20 \%$ & $80 \%$ & - & - \\
\hline \multirow{5}{*}{$\begin{array}{l}\text { 3. The } \\
\text { Weakness } \\
\text { of TPR } \\
\text { Method }\end{array}$} & 11. & $\begin{array}{l}\text { I do not understand } \\
\text { when i learn } \\
\text { thorugh this method }\end{array}$ & - & - & $20 \%$ & $80 \%$ \\
\hline & 12. & $\begin{array}{l}\text { This method is less } \\
\text { fit to use at the time } \\
\text { of learning }\end{array}$ & - & - & $80 \%$ & $20 \%$ \\
\hline & 13. & I feel bored quickly & $6,66 \%$ & - & - & $93,33 \%$ \\
\hline & 14. & $\begin{array}{l}\text { I prefer learning by } \\
\text { way of discussions, } \\
\text { lectures etc, rather } \\
\text { than using this } \\
\text { method }\end{array}$ & - & - & $33,33 \%$ & $66,66 \%$ \\
\hline & 15. & $\begin{array}{l}\text { I can not improve } \\
\text { my learning ability } \\
\text { through this method }\end{array}$ & - & - & $46,66 \%$ & $53,33 \%$ \\
\hline
\end{tabular}

The reseacher devided that table to 3 part in each category and the quistionnaire covered fifteen question and dealt with classroom interaction. This quistionnaires were delivered to the students, one sheet quistionnaire for one student.

\section{a. Students' Perception Toward TPR Activity}


The first part on the quistionnaire is the students perception toward the TPR activity in the classroom while learning English vocabulary. The question in this part devided by five questions. All students were interested learning english vocabulary combined with TPR method. They were enjoyed learning english, increasing participation in the classroom activity, and for the teacher can give the technique for learning english with this method and for students can increasing their vocabulary. The result on the table have a good reaction for achievement for students and also the teacher.

Table 1.1

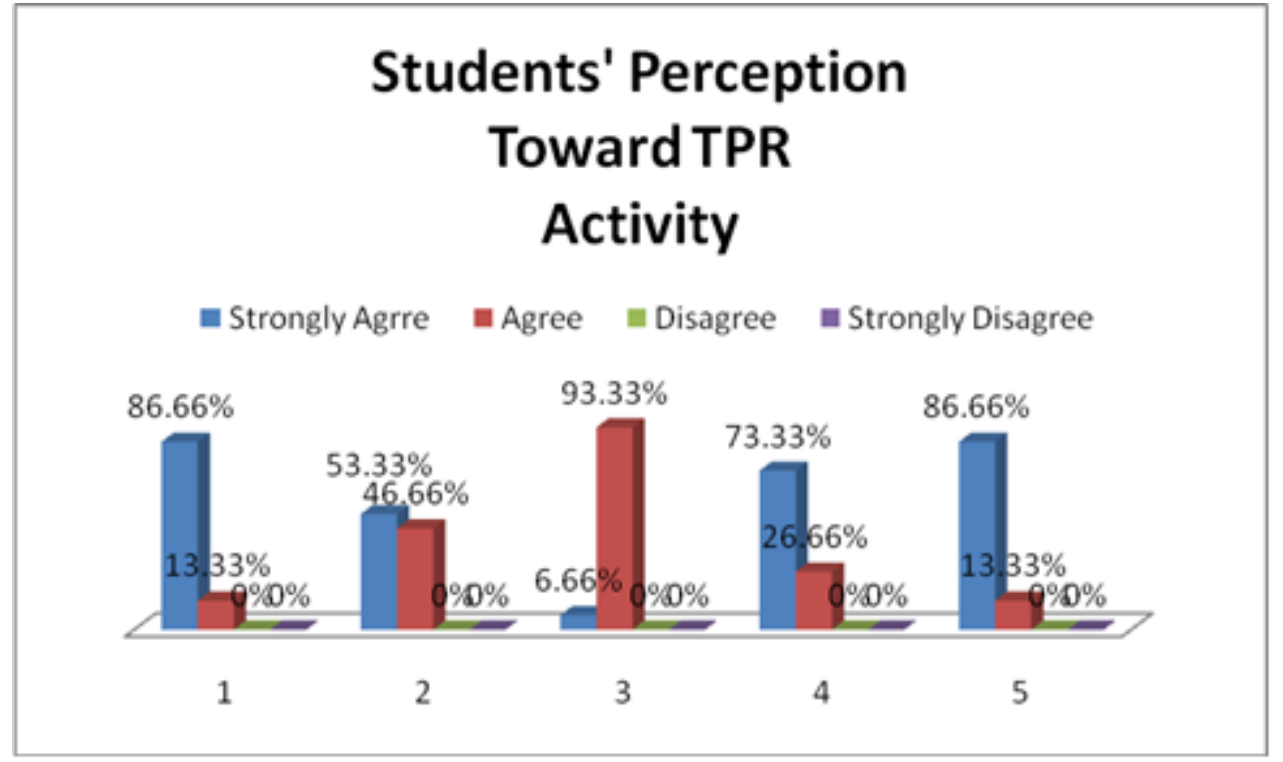

From the table 1.1 above, students who answered question number one were strongly agree means $86,66 \%$ and agree $13,33 \%$ that they are feel easier learning vocabulary with TPR method. They are so attractive and active while the classroom participation. The students answered question number two were strongly agree 53,33\% and agree 46,66\% that they can understand faster when learning with this method. For the question number three, that is significant answered from student that students who answered strongly agree 93,33\% and agree 6,66\% when the students were enjoyed learning with this method. For this question, the reseacher is very shocked when heared the answer from students beacause mostly they are very enjoyed learning when using this TPR method. Then, for the question number four the students answered strongly agree $73,33 \%$ and agree $26,66 \%$ that they are can get new information when learning with this method. Student 1 give an opinion about this method to the teacher, he said that "Miss, now i know the vocabulary of 'tipe $x$ ' is correction pen. Thank you, miss". Last, the students answered question number five is same with question number one for the statement is they are love learning vocabulary with this method. When the students learning with this method, there is a lot of things that the students to do when classroom activity.We have concluded that this method is intersting for students when they are learning english vocabulary with this method and they are enjoyed while instructional in the classroom.

\section{b. Students' Perception Toward The Benefit of TPR}

The second part for the quistionnaire is the perception about the the benefit of TPR method in the classroom while learning English vocabulary. This question in this part devided by 
five questions. All students are very active when learning english vocabulary combined with TPR method. Some student had a good opinion for this method.

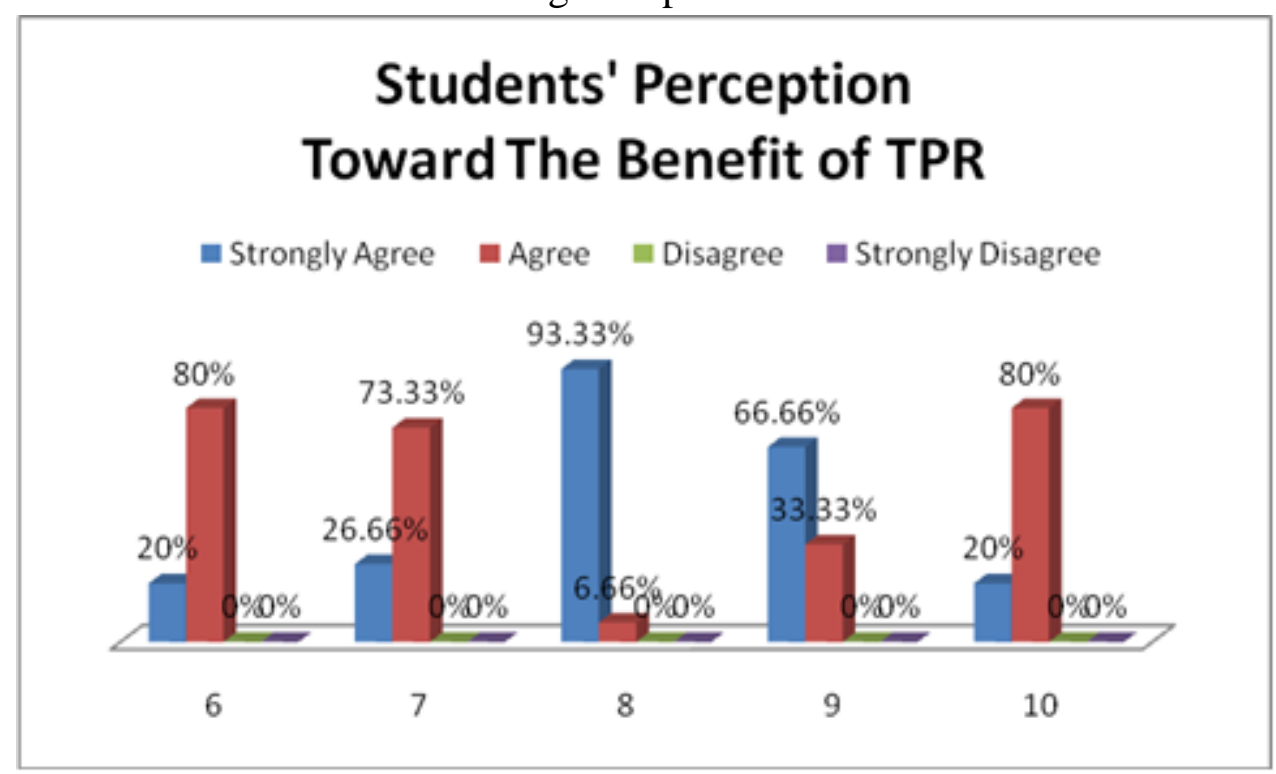

From the table 1.2 above, students who answered question number six were strongly agree means $20 \%$ and agree $80 \%$ that they are can get more information when learning with this method. Some students who have a good intellengence were helped learning with this method. Students who answered question number seven were strongly agree $26,66 \%$ and agree $73,33 \%$ for the statement of they are able to learn the material through this method. Many students can follow the instructional when learning with TPR method, the teacher and the students are have a good classroom interaction. For question number eight, the researcher is very happy that a significant answered from the students that strongly agree 93,33\% and agree 6,66\% from the statement they are feel happy when learning with TPR method. The researcher found some good opinion from some student SMPN 2 Plered. Student 1 give an opinion in this method "I like learning english with this method" and he is very active in the classroom when learning. Student 2 give an opinion in this method "I can find the new vocabulary with this method" and she shared with other student in the classroom when she had a new vocabulary. Asher (2003) mentions some advantages of TPR method. He claimed that TPR is useful to assist students in learning a target language instantly by having them engage in a stress-free situation and fun activities.From the expert statement, with this method the students can reduce their stress and create a fun learning. Then, the students who answered question number nine are strongly agree 66,66\% and agree $33,33 \%$ that they are can learn faster with this method than other method when learning vocabulary. This method is easy to understand because learning with this method can help the students increasing learning by kinesthetic. For kinesthetic learner, that is a good method to help their learning. Last, the students answered question number ten are strongly agree $20 \%$ and agree $80 \%$ for the statement of they are motivated when learning vocabulary with this method. When classroom activity, mostly students are interested learning vocabulary with TPR method. 


\section{c. Students' Perception Toward The Weakness of TPR}

The third part for the quistionnaire is the perception about the the weakness of TPR method in the classroom while learning English vocabulary. This question in this part devided by five questions. Mostly, they are liked learning with this method. The result is showed by the response from students.

Table 1.3

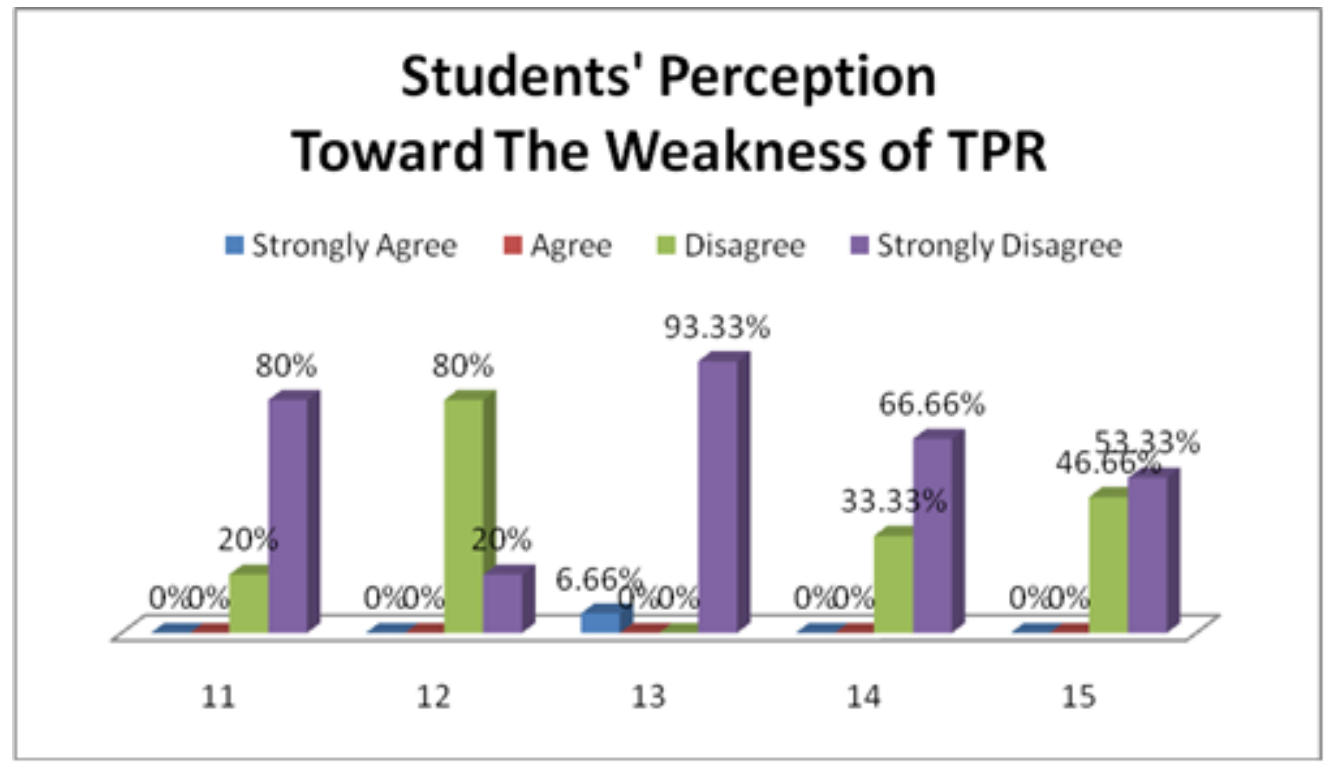

From the table 1.3 above, students who answered question number eleven were strongly disagree $20 \%$ and strongly disagree $80 \%$ that they are do not understand when learning with TPR method. Overall, they are understand when the teacher giving material in the classroom activity and active classroom participation. The students who answered question number twelve are disagree $80 \%$ and strongly disagree $20 \%$ from the statement TPR method is less fit to use at the time when learning english vocabulary. They claimed that with this method, the students are passed by combined learning english vocabulary. For question number thirteen, that is a significant answered from students. The students are answered strongly agree 6,66\% and strongly disagree 93,33\%. The researcher asked student who answered agree for the weakness for this method. Student 1 give an opinion the weakness in this method "I don't like learning with this method, because this method is boring for me". He also feel like confused when he learning with this method. But overall, mostly student are enjoyed and active when learning with this method. Then, for question number fourteen the students answered disagree 33,33\% and strongly disagree $66,66 \%$ that they are like learning with TPR method prefer than using other method like discussions or other method when learning english vocabulary. The researcher asked two students for giving their opinion. Student1 give an opinion "miss, i like learning english vocabulary with TPR method because if learning english with discussions that is not effective for me". student2 give an opinion "miss, when learning english vocabulary with this method i can get the new vocabulary and share to my friend". From both of opinion, mostly student like learning english vocabulary with TPR method. Last, for question number fifteen the students are answered disagree 46,66\% and strongly disagree 53,33\% that they claimed can not improving their vocabulary when learning with TPR method. 
When the researcher asked students, mostly they are answered that they are can improve their vocabulary in english by using TPR method.

\section{d. Interview}

The second to get information for this research is with interview the students. This interview is to find the problem or get more information besides with questionnaire. The interview also is to find the specific answered from the students. The question delivered to 15 students in the classroom and the question is "Why do you interested learning english vocabulary with TPR method?". The result is on the table.

Table 1.4

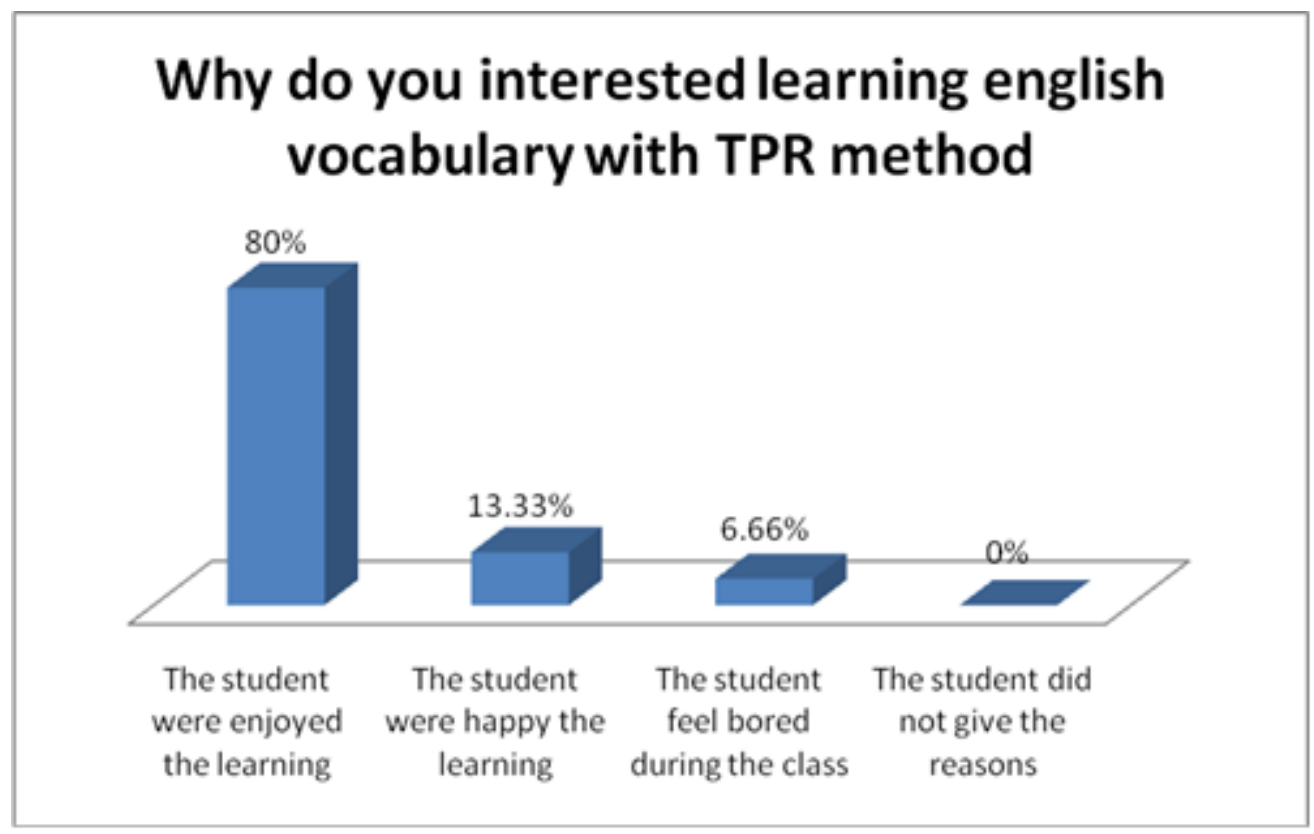

From the table 1.4 above, the result from the question "Why do you interested learning english vocabulary with TPR method", the students who answered enjoyed $80 \%$, happy $13,33 \%$ and boring $6,66 \%$. First, the students who answered they are enjoyed the learning by using TPR method, they claimed that TPR method is useful for learning english vocabulary and increasing classroom participation between the teacher and the students. Second, the students who answered they are happy the learning by using TPR method, they are giving an opinion about that method. They are said "miss, we are feel happy and easier learning english vocabulary by using TPR method because we can share our vocabulary between us". Last, the students who answered they are feel bored learning english vocabulary by using TPR method, he stated that "i do not like learning english vocabulary by using TPR method, miss". The researcher giving add question for who answered boring, "Why you so boring?". Student 1 answered "i feel like confused and i don't know about the vocabulary for example vocabulary of 'meja' and also shy to speak english". He is scared and confused when learning english in this method. 


\section{CONCLUSION AND SUGGESTION}

\section{Conlusion}

The conclusion in this research is this method is good for delivered to the students when learning english vocabulary. Mostly, students are enjoyed, happy and active when learning english vocabulary by TPR method and increasing classroom participation. This method also conducted by the result from questionnaire and interview. From the questionnaire, the students who answered strongly agree is $80 \%$, agree $13,33 \%$ and strongly disagree $6,66 \%$. They claimed that they are very enjoyed, happy and interesting when they are learning english vocabulary by using TPR method. For the interview, the student answered strongly disagree have an opinion from his statement "i felt like confused and don't know about the vocabulary". The student who give that opinion, he claimed that he can not learning english. It means that he do not want learning english while he in school and also when he learning english subject. The researcher give some teraphy for him, to encourage him to want learning english. Overall, mostly students weres enjoyed and active when learning english vocabulary with this method. They are attractive and increasing classroom participation when learning english vocabulary by using TPR method.

\section{Suggestion}

The writter hopes for the next researcher especially who will research their researching same title, same method or like this research that the research can find the new information to the next research and this research can be as reference for the research. The researcher suggest with this method can give the different way or style of learning when the teacher delivered the material english subject, for the teacher because the problem when teach students are complex, the reseacher hopes by using TPR method the teacher can have new style in learning english to delivered to the students. For the students, the researcher hopes that by using TPR method can make solve the problem for learning english vocabulary because vocabulary is basic to learn english. For example to speak with other people from another country, speak english is the most important point to communicate with each other. The researcher also hopes for the teacher and the students can make a good interaction learning english by using TPR method because learning is not wasting time for your life, so we have to learn, learn learn until we are death.

\section{REFERENCES}

Alqathani, M. (2015). 'The Importance of Vocabulary in Language Learning and How to be taught'. International Journal of Teaching and Education, 3(3), 21-34, available:

www.iises > publication-detail-213 [accessed 21 March 2017]

Alwasilah, A. C. (2002). Pokoknya kualitatif: Dasar-dasar Merancang dan Melakukan

Penelitian Kualitatif. Jakarta. Pustaka Jaya.

Arikunto, Suharsimi. (2002). Prosedur Penelitian : Suatu Pendekatan Praktek. Jakarta :

PT.Rineka Cipta

Asher, James. (2003). Update for The Total Physical Response. Retrieved on October 16th 2014. Available at http://www.tpr-world.com

Baron, R. A. (1995). Physicology. USA: Simon and Schuster company

Brown, H. Douglas. 2004. Language Assessment Principles and Classroom Practice. New

York: Pearson Education 
Cameron, L. (2001). Teaching Languages to Young Learners. Cambridge: Cambridge University Press

Departemen Pendidikan Nasional. (2003). Standar Kompetensi Mata Pelajaran Bahasa Inggris: Sekolah Menengah Atas dan Madrasah Aliyah. Jakarta: Depdiknas.

Hatch, E and Brown, C. (1995). Vocabulary, semantics, and language education. Cambridge:

Cambridge University Press

McMillan, J. (2001). Research in Education A Conceptual Introduction, Wesley Longman.

Nunan, D. (1991). Language teaching methodology. New York: Cambridge University Press.

Richard, C. Jack and Rodgers, S. Theodore (1986) Approach and method on language

teaching. United Kingdom: Cambridge University press.

Richard, J.C and Rodgers, T.S. (2001). Approaches and methods in language teaching.

United Kingdom: Cambridge University Press.

Rakhmat, Pareek \& Alex. (2003). Psikologi Komunikasi. Bandung : PT. Remaja Rosdakarya Sadikin, I. S. (2016). 'The Use Of Webquest for Teaching English Vocabulary In An EFL Young Learners Context'. Proceeding of International Conference on Teacher Training and Education, 1(1), 403-410, available: www.jurnal.fkip.uns.ac.id/index.php/ictte/article/view/7636 [accessed 4 February 2018]

Sudjana. 1984. Metode Statistika. Bandung: Tarsito

Suryan, L.I. 2004. Psikologi Umum II. (sensasi dan persepsi). Bandung: Universitas Islam Bandung. Fakultas Psikologi.

Widodo, H. P. (2005). 'Teaching children using a total physical response (TPR) method: Rethinking'. Bahasa Dan Seni, 2(2), 235-248. 